\title{
GAPDH wt Allele
}

National Cancer Institute

\section{Source}

National Cancer Institute. GAPDH wt Allele. NCI Thesaurus. Code C104410.

Human GAPDH wild-type allele is located in the vicinity of 12p13.31 and is approximately

$4 \mathrm{~kb}$ in length. This allele, which encodes glyceraldehyde-3-phosphate dehydrogenase protein, plays a role in carbohydrate metabolism. 